\title{
強潮流が操綾運動に及ぼす影響
}

\author{
丹羽康之*・沼野正義*・福戸淳司*・多田光男**
}

\section{Effect on Ship Maneuvering Motion under Strong Tidal Current}

\author{
Yasuyuki NIWA, Masayoshi NUMANO, Junji FUKUTO and Mitsuo TADA
}

\begin{abstract}
Authors have been making observation on the tidal current and its effect on the ship motion along Kurushima Strait. An appropriate maneuvering control is essential for the safety navigation under a strong current condition. The ship maneuvering motion was analyzed using a simple response model, $\mathrm{i}$. e., a KT model. Although the difference between an estimated motion by the KT model and the actual motion shows the effect of the current, a strong transient phenomenon, a side slip motion of the ship, was observed especially in entering the strongest part of the current. As the detection of the side slip is essential for the ship control, a continuous watch on water surface in front of the ship and monitoring splashing sound around bow gives effective information about the transient phenomenon.
\end{abstract}

\section{1.はじめに}

来島海峡は屈曲した狭水道であり、強潮流が発生 する故、順潮時は中水道を逆潮時は西水道を航行す るという「順中逆西」という航法がとられている。 しかしながら転流時の水道通航の禁止により、時間 帯によって水道入口での船の滞留が発生する他、海 峡出入り口付近での航路の交差のために、昔から衝 突事故や座礁などが多発する難所の一つである。そ のため、潮流の向きに関係なく右側通航とする提案 もあるが、それを実現するためには、強潮流下にお いて潮流が操縦運動性能に与える影響を明らかに し、潮流に応じた安全な操船方法を確立する必要が ある。

これまでに著者らは実際に来島海峡の潮流分布の 観測を行い、潮流分布は地形効果による影響で流向 に大きな変化があることを示し(1)、潮流と船速の増 減の関係について検討を行った(2)。

そこで今回は、潮流が操縦運動性能に及ぼす影響 を明らかにするために、対象船舶である弓削丸の操 縦運動性能を $Z$ 試験で推定し、潮流の影響のない状
態での操縦運動方程式を求めた。そして潮流下での 航行の際の回頭角速度に着目し、操縦運動方程式か ら求まる推定值と実際の観測結果を比較し、操縦運 動方程式の有効性について考察を加えるとともに、 潮流が操縦運動性能に与える影響の推定を試みた。

\section{2. 観測概要}

観測は国立弓削商船高等専門学校の練習船「弓削 丸」で行った。本船の主要目は、長さ $40 \mathrm{~m}$ 、幅 (型) $8 \mathrm{~m}$ 、満載揳水 $($ 型) $2.8 \mathrm{~m}$ 、総卜ン数 240 トンである。 潮流の観測には超音波ドップラー流速計(米国RD 亿 ンスツルメント社製 $300 \mathrm{kHz}$ 型)を用いた。今回は水 深 $5 \mathrm{~m}$ から $2 \mathrm{~m}$ 間隔18層について、東西、南北、鉛直 の各方向成分を観測することにより、3 次元分布を 得た。サンプリング時間は約15秒間隔であった。同 時に船体運動収録装置で、時刻、舵角、CPP翼角、 回頭角速度、船首方位、X (船首尾方向) 対地船速· $\mathrm{Y}$ (船横方向) 対地船速、緯度・経度、真風向・真風 速を観測した。サンプリング時間は 1 秒間隔であっ た。またビデオカメラにより、船首方向の海面を記 録した。観測前にすべての装置の時刻をGPS時刻に

* 正会員 海上技術安全研究所（干181-0004 東京都三鷹市新川6-38-1）

**正会員 弓削商船高等専門学校（干794-2593 愛媛県越智郡弓削町下弓削1000番地） 


\section{表 1 観測概要}

\begin{tabular}{|c|c|c|c|c|c|c|c|c|}
\hline 観測No. & 日付 & 通航方向 & 通航水道 & 潮流方向 & $\begin{array}{l}\text { 航路IN時刻 } \\
\text { 航路OUT時刻 }\end{array}$ & \begin{tabular}{|l|} 
潮汐表による \\
推定潮流 (※)
\end{tabular} & $\begin{array}{l}\text { 設定船速 } \\
\text { CPP翼角 }\end{array}$ & 備考 \\
\hline 1 & 9月 27 日 & 東 $\rightarrow$ 西 & 西水道 & 南流 $\rightarrow$ 北流 & $\begin{array}{l}09: 56 \\
10: 59 \\
\end{array}$ & $\begin{array}{l}+3.32 \mathrm{knot} \\
-0.47 \mathrm{knot} \\
\end{array}$ & $\begin{array}{c}9 \mathrm{knot} \\
9 \mathrm{deg}\end{array}$ & \\
\hline 2 & 9月 27 日 & 西 $\rightarrow$ 東 & 西水道 & 北流 & $\begin{array}{l}11: 33 \\
12: 39 \\
\end{array}$ & $\begin{array}{l}-2.55 \mathrm{knot} \\
-5.96 \mathrm{knot}\end{array}$ & $\begin{array}{c}9 \mathrm{knot} \\
9 \mathrm{deg}\end{array}$ & \\
\hline 3 & 9月 27 日 & 東 $\rightarrow$ 西 & 中水道 & 北流 & $\begin{array}{l}12: 55 \\
13: 35 \\
\end{array}$ & $\begin{array}{l}-6.57 \mathrm{knot} \\
-7.61 \mathrm{knot} \\
\end{array}$ & $\begin{array}{r}9 \mathrm{knot} \\
9 \mathrm{deg}\end{array}$ & \\
\hline 4 & 9月 27 日 & 西 $\rightarrow$ 東 & 西水道 & 北流 & $\begin{array}{l}13: 52 \\
15: 11 \\
\end{array}$ & $\begin{array}{l}-7.81 \mathrm{knot} \\
-6.82 \mathrm{knot} \\
\end{array}$ & $\begin{array}{c}9 \mathrm{knot} \\
9 \mathrm{deg} \\
\end{array}$ & $\begin{array}{l}\text { 強潮流時間带 } \\
\text { Max. }-7.88 \mathrm{knot}(14: 06) \\
\end{array}$ \\
\hline 5 & 9月 27 日 & 東 $\rightarrow$ 西 & 中水道 & 北流 & $\begin{array}{l}15: 28 \\
16: 01 \\
\end{array}$ & $\begin{array}{l}-6.19 \mathrm{knot} \\
-4.62 \mathrm{knot} \\
\end{array}$ & $\begin{array}{l}13 \mathrm{knot} \\
16 \mathrm{deg}\end{array}$ & \\
\hline 6 & 9月 27 日 & 西～$\rightarrow$ 東 & 西水道 & 北流 & $\begin{array}{l}16: 17 \\
17: 01 \\
\end{array}$ & $\begin{array}{l}-3.71 \mathrm{knot} \\
-0.87 \mathrm{knot} \\
\end{array}$ & $\begin{array}{r}13 \mathrm{knot} \\
16 \mathrm{deg} \\
\end{array}$ & 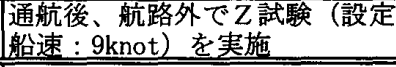 \\
\hline 7 & 9月 28日 & 東 $\rightarrow$ 西 & 西水道 & 南流 & $\begin{array}{l}09: 42 \\
10: 50 \\
\end{array}$ & $\begin{array}{l}+6.69 \mathrm{knot} \\
+3.10 \mathrm{knot} \\
\end{array}$ & $\begin{array}{c}9 \mathrm{knot} \\
9 \mathrm{deg} \\
\end{array}$ & \\
\hline 8 & 9月 28 日 & 西 $\rightarrow$ 東 & 中水道 & 南流 $\rightarrow$ 北流 & $\begin{array}{l}11: 05 \\
11: 58\end{array}$ & $\begin{array}{l}+2.12 \mathrm{knot} \\
-1.47 \mathrm{knot}\end{array}$ & $\begin{array}{c}9 \mathrm{knot} \\
9 \mathrm{deg}\end{array}$ & \\
\hline 9 & 9月 28 日 & 東 $\rightarrow$ 西 & 中水道 & 北流 & $\begin{array}{l}12: 22 \\
13: 06\end{array}$ & $\begin{array}{l}-3.03 \mathrm{knot} \\
-5.56 \mathrm{knot} \\
\end{array}$ & $\begin{array}{c}9 \mathrm{knot} \\
9 \mathrm{deg}\end{array}$ & \\
\hline 10 & 9月28日 & 西 $\rightarrow$ 東 & 西水道 & 北流 & $\begin{array}{l}13: 21 \\
14: 37\end{array}$ & $\begin{array}{l}-6.27 \mathrm{knot} \\
-8.31 \mathrm{knot}\end{array}$ & $\begin{array}{c}9 \mathrm{knot} \\
9 \mathrm{deg}\end{array}$ & 強潮流時間带 \\
\hline
\end{tabular}

※来島海峡中水道標準点。南流を正、北流を負とする。

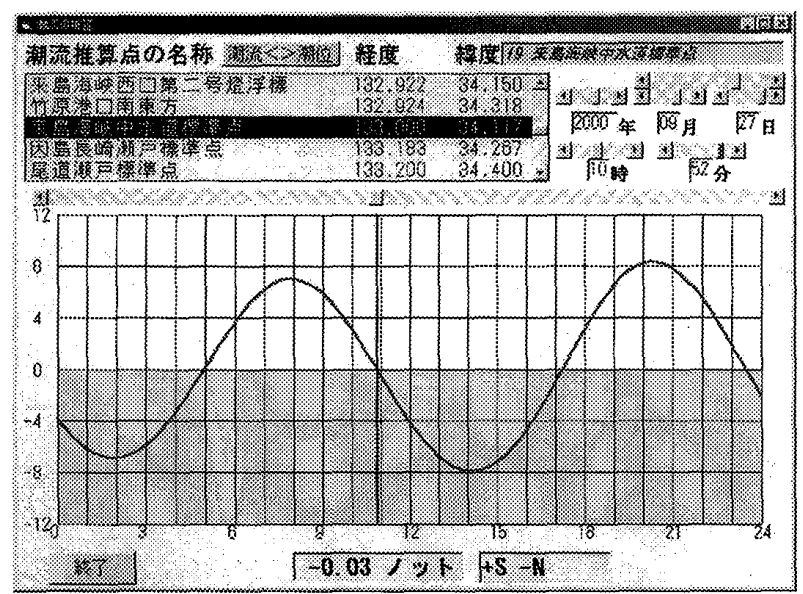

困 1 (a) 観測日の潮流（9月27日）

合わせている。

観測は平成12年 9 月27日、28日の 2 日間にわたつ て行った。来島海峡航路を通常の通航力法に従って、 繰り返し往復し、2 日間で中水道 4 回(北航：3 回、 南航：1 回)、西水道 6 回(北航：2 回、南航：4 回)、 延べ10回観測を行った。表 1 に観測時の航行の概要 を示す。

観測日の潮流（潮汐表加ら推定：来島海峡中水道 標準点) を図 1 (a)、（b）に示方。なお今回の観測時 の潮流最強時は 9 月28日14時37分であり、潮流は北 流8.31ノット $(4.27 \mathrm{~m} / \mathrm{s})$ であった。

超音波ドップラー流速計による潮流観測值、船体 運動収録装置による各種観測值の信頼度を高めるた め、観測期間の一通航中はCPP翼角を常に $9 \mathrm{deg}$ も しくは16 degの二種類のいずれかになるようにし た。超音波ドップラー流速計による潮流観測値の標

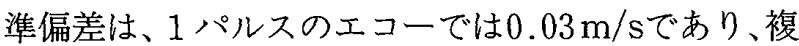
数パルスのデー夕を採用することにより、信頼度を

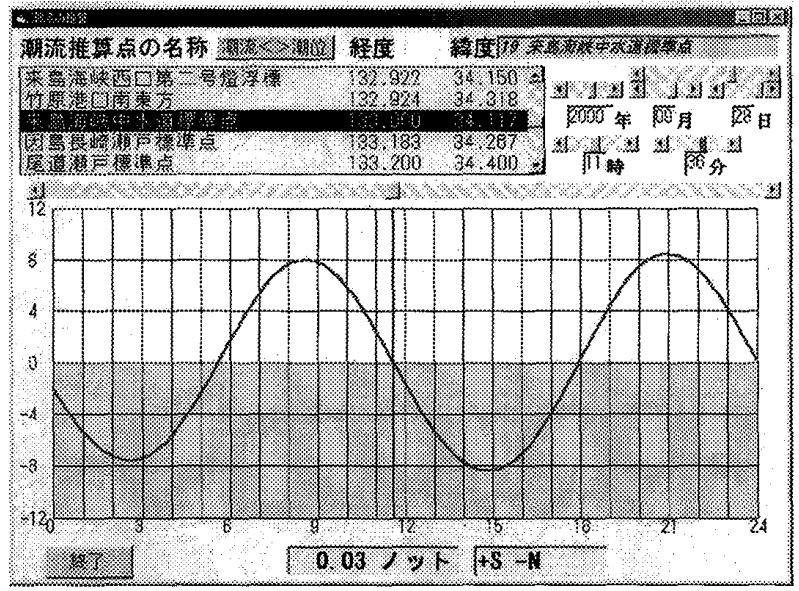

困 1 (b) 観測日の潮流（9月28日）

高めている。CPP翼角の $9 \mathrm{deg} も し く は 16 \mathrm{deg}$ 零 水中を航行中する場合であれば、それぞれ対水船速 が 9 ノット $(4.5 \mathrm{~m} / \mathrm{s}) 、 13 / ッ ト ~(6.5 \mathrm{~m} / \mathrm{s})$ に相当 するものである。この対水船速を設定船速と呼ぶ。 今回の解析では、設定船速 9 ノット $(4.5 \mathrm{~m} / \mathrm{s})$ のデー 夕を用いる。

\section{3. 観測・解析結果}

\subsection{Z試験の結果および操縦運動方程式}

9 月27日の第 6 回目の観測後、来島海陝東側の航 路外で標準的な $Z$ 試験である舵角 $10 \mathrm{deg} /$ 回頭角 10 $\operatorname{deg}$ の試験を行った。設定船速は 9 ノット $(4.5 \mathrm{~m} / \mathrm{s})$ とした。困 $2(\mathrm{a})$ に舵角 $\delta[\mathrm{deg}]$ と船首方向変位の結 果を示す。また $Z$ 試験の結果を 1 次系近似の操縦運 動方程式（KTモデル）

$$
T d r / d t+r=K\left(\delta+\delta_{r}\right)
$$

を仮定したところ、操縦性指数は $K=0.2[1 / \mathrm{s}] 、 T=$ 


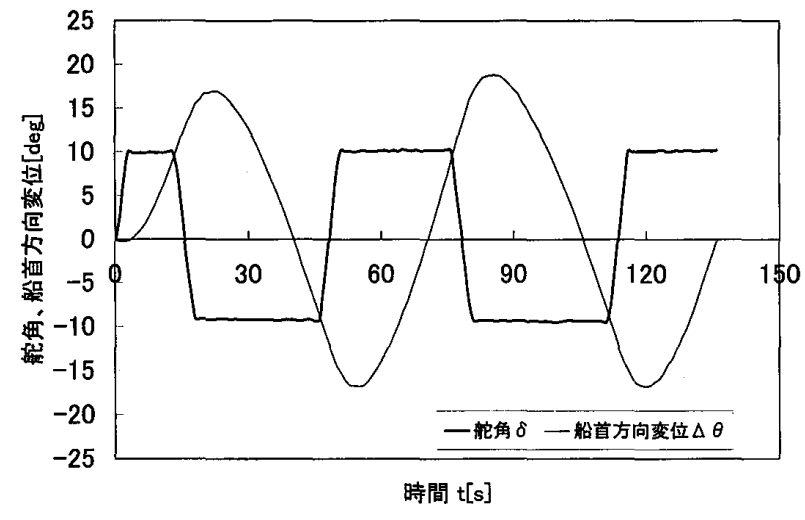

図 2 (a) Z試験結果（舵角、船首方位変位）

$12[\mathrm{~s}] 、$ 当て舵量 $\delta_{r}=1.2[\mathrm{deg}]$ がその推定值として得 られた。観測された回頭角速度 $、$ 、推定した操縦性指 数および観測結果の舵角 $を$ 利用して求めた推定回 頭角速度 $r_{K T}$ を図 $2(\mathrm{~b})$ に示寸。

風の影響については、Z試験開始時の進行方向に 対して、右 $60 \mathrm{deg}$ 方向から平均 $1.1 \mathrm{~m}$ と弱いもので あった。また弓削丸の船橋はほぼ船体の中央である ため、風による旋回への影響は小さいものと考えら れる。

なおZ試験時の潮流は $0.5 \mathrm{~m} / \mathrm{s}$ 以下かつほぼ一定 であった。よって式(1)は、平水中での適用ができる と考える。

\section{2 船体運動へ影響する潮流のモデル化と解析 方法}

強潮流下で船体に働く運動は、通常の舵による運 動と、潮流による回転運動と並進運動が重畳された ものと仮定し、実際に観測した回頭角速度から $K T$ モデルを用いた推定回頭角速度の差を求め、潮流に よる影響を推定する。

しかしながら実際には単なる重畳だけではなく、 式（1）に従わない過渡現象も起きると考えられるた め、この点についても解析を行う必要がある。そこ で平水中と潮流下での違いを検討するために、対地 速度と潮流加ら対水速度を推定し、船体と潮流の相 対的な関係を明らかにし、式(1)が適用できるのか、 それともそれに従わない過渡現象が起こっている か、起きているとすればどのような過渡現象が起き ているのかを考察する。

さらに同時に観測したビデオ画像を利用して、過 渡現象の確認と把握を行う。

\section{3 解析対象範囲}

図 3 は観測結果の可視化ソフトウェア ${ }^{(3)}$ の画面 である。9 月27日の第 4 回目の観測結果の航跡、水 深 $5 \mathrm{~m}$ の潮流抢よび地形を表示している。本ソフト ウェアは任意の方向から鳥瞰図として眺めることが

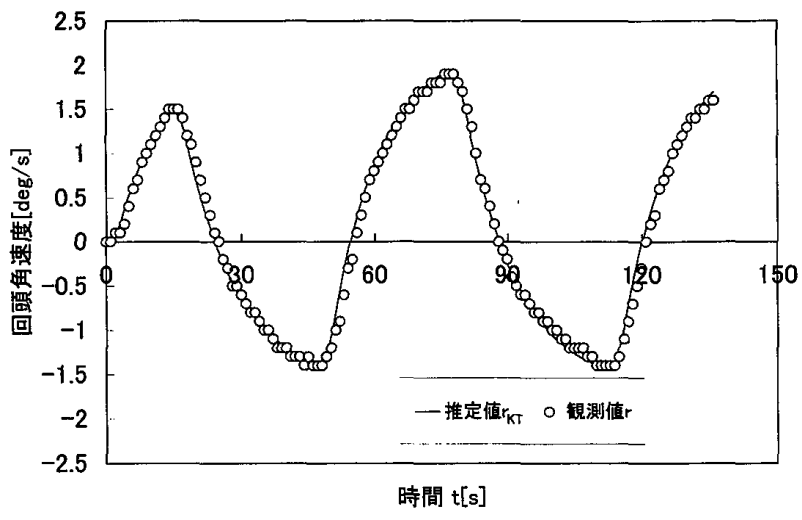

困 2 (b) Z試験結果（回頭角速度）

可能であるが、ここでは上空から鉛直下向きに眺め た画面を表示している。潮流は水深 $5 \mathrm{~m}$ 加 $2 \mathrm{~m}$ 間 隔で観測したが、水深 $5 \mathrm{~m}$ から $15 \mathrm{~m}$ の範囲では、流 速・流向ともほぼ同様の傾向であることを確認して いる。今回の船体運動に影響する潮流の解析におい て、潮流の代表值は、水深 $5 \mathrm{~m}$ の観測結果を利用寸 ることとする。

図 3 は西水道の入口に向かって、西から東へ航行 し、小島・馬島間を通航するために、右へ旋回する 場面を中心としたものである。潮流分布に着目する と、A地点付近では、小島の影となっているため、 0.5 $\mathrm{m} / \mathrm{s}$ 以下と非常に小さな值を観測している。その後、 小島・馬島間を流れる潮流の影響により、北向きの 潮流に出会うが、これに抗して右へ旋回し、南へ航 行している。そこで今回は船体運動に影響する潮流 の解析の対象範囲を、潮流の弱い場所から、強潮流 に対して斜们進入し、さらに旋回を行うという一 連の動作の範囲とする。具体的な範囲は、図 3 のA地 点（9 月27日、14時19分53秒、 $t=0[\mathrm{~s}]$ とする）から B地点（9 月27日、14時26分44秒、 $t=411[\mathrm{~s}]$ ）まで の 7 分弱の時間である。この間の潮流観測点数は約 15秒間隔、27点である。

\section{4 潮流影響の推定}

3.1節で求めた操縦性指数および実際の舵角から、 平水中を航行していると仮定して、式(1)を用いて、 推定回頭角速度 $r_{K T}$ を求好る実際に観測した回頭 角速度 $r$ と推定回頭角速度 $r_{K T}$ との差 $\Delta r$ を潮流等の 外乱影響の推定值として求める。

$$
\Delta r=r-r_{K T}
$$

図 4 の(a)から (e) は，順番に船首方位 $\theta$ 、舵角 $\delta$ 、 回頭角速度 $r$ 、推定回頭角速度 $r_{K T}$ 、外乱 $\Delta r$ を示して いる。また図 4 (a)に潮流観測区間 (27区間) 番号を 示す。図 4 (e)の值が潮流等の外乱影響の推定值であ るが、 $t=0[\mathrm{~s}]$ から $t=90[\mathrm{~s}]$ までの範囲（区間 1 か 


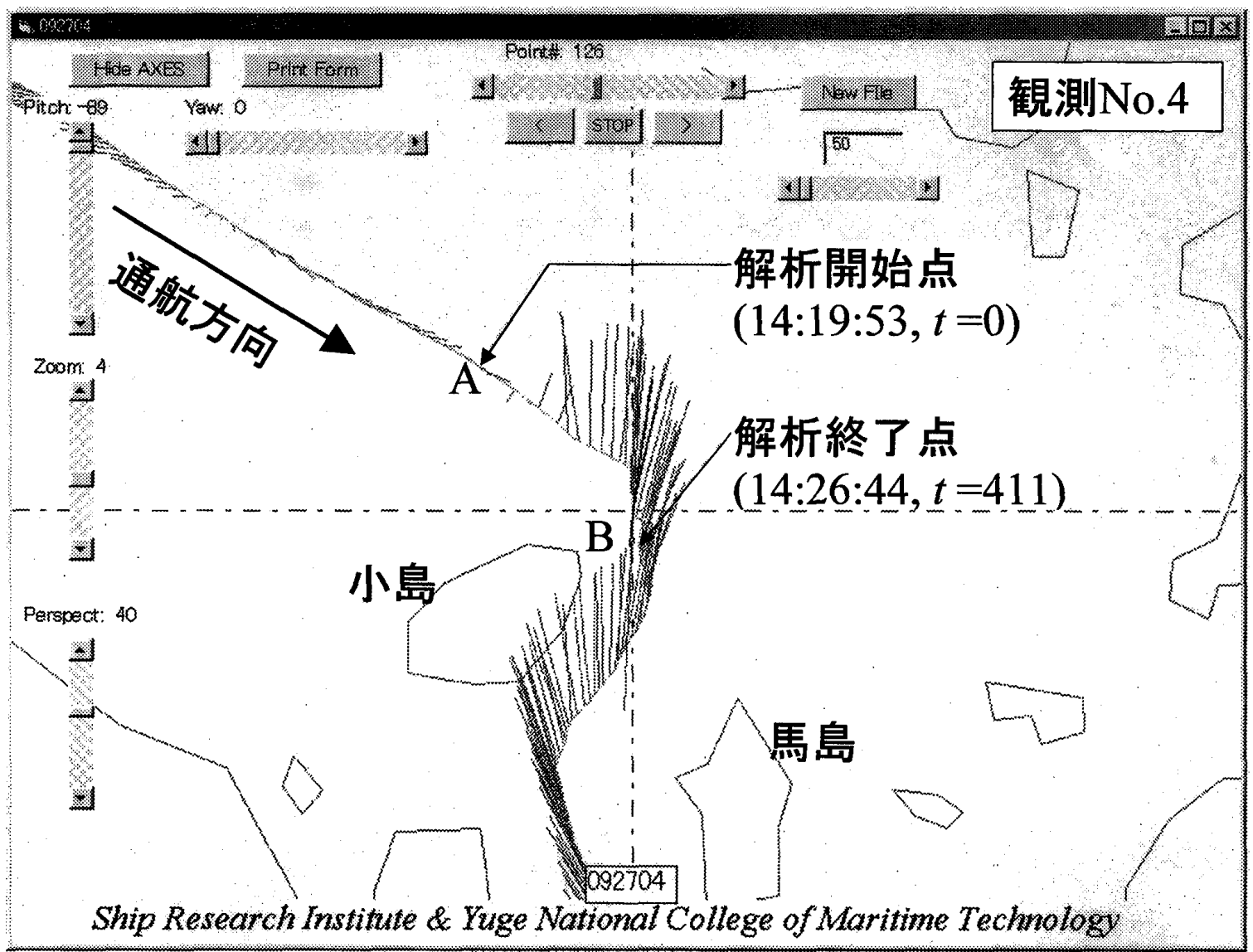

図 3 観測結果

ら区間 6）では、小さな值であり、潮流影響が小さ いことを示している。その後潮流に対して斜めに進 入し、右へ旋回していく $t=90[\mathrm{~s}]$ から $t=175[\mathrm{~s}]$ ま での範囲（区間 7 から区間12）では、負の值、すな わち船首が左側へ振られる外乱が働いていることが わかる。これは右前方からの強潮流部分に進大寸る ことにより、回転モーメントが発生するためと考え られるが、3.5節で後述する斜航状態になること等に よる影響も含まれると考えられる。 $t=175[\mathrm{~s}]$ から $t=310[\mathrm{~s}]$ の範囲（区間13から区間21）では、外乱影 響は小さな值である。なお区間19で今回の解析区間 では最強の潮流 $3.8 \mathrm{~m} / \mathrm{s}$ 観測された。この区間は強 潮流区間であるものの、潮流の流向に大きな変化が ないことを確認した。このため、式(1)が適用できる 範囲の運動であると考之られる。 $t=310[\mathrm{~s}]$ から $t=$ 345 [s] の範囲（区間22から区間23）で、再び、大き な外乱が働いている。この外乱影響は3.6節で後述す るビデオ画像を利用することにより、潮目に突入し て船首が振られていることを確認している。

以上、 $K T$ モデルから推定した回頭角速度 $r_{K T}$ と

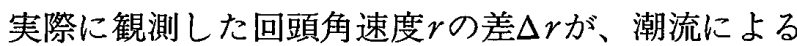
影響と仮定して推定した。しかしながら、実際には $r_{K T}$ が有効でない現象が起きていることも考えられ
るので、船体の対水運動について着目した。

\section{5 対水速度の推定および過渡現象}

推定回頭角速度 $r_{K T}$ はZ 試験の実験結果を基に推 定しているが、Z試験の実験条件は平水中である。そ のため、実際に来島海峡のような強潮流下において 適用可能なのか考察する必要がある。そこで、四 5 に示すように、対地速度べクトルと潮流べクトルの 差をとることにより、对水速度べクトルを推定する こととした。なお潮流は解析区間のほぼ全範囲で、 サンプリング数の 80 パーセント以上が標準偏差0.03 $\mathrm{m} / \mathrm{s}$ 内に収まる信頼度を有している。

図 6 (a)は、Z試験時の対水速度を図 5 に基づき推 定したものである。大きな変針をとる航行であるが、 潮流が一様で弱く平水中に近い状態における航行の ため、対水速度の横方向成分 (Y対水速度) は小さな 值を示している。すなわち対水速度は船首方位と一 致しており、斜航状態はみられない。

一方、図 6 (b) は、解析対象範囲の対水速度の推定 值である。解析区間の前半である $t=0[\mathrm{~s}]$ から $t=$ 77 [s] までの範囲（区間 1 から区間 5 ）は、比較的潮 流が弱い区間であり、○印で示している。対水速度 の横方向成分（Y対水速度）は小さな值を示してお ク、平水中での $K T$ モデルが適応できる範囲である 


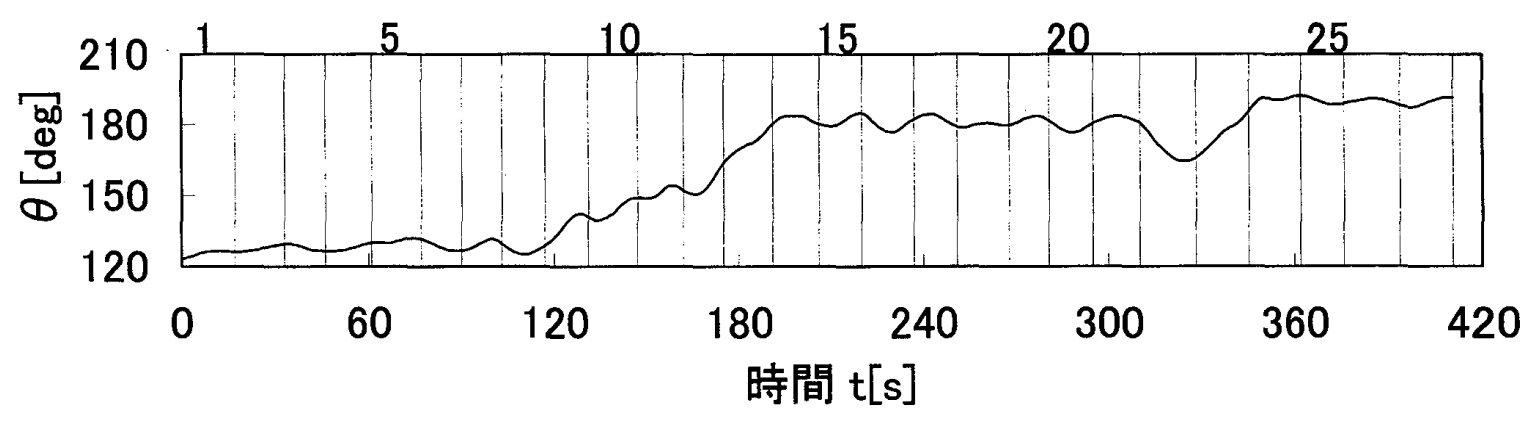

困 4 (a) 船首方位変化

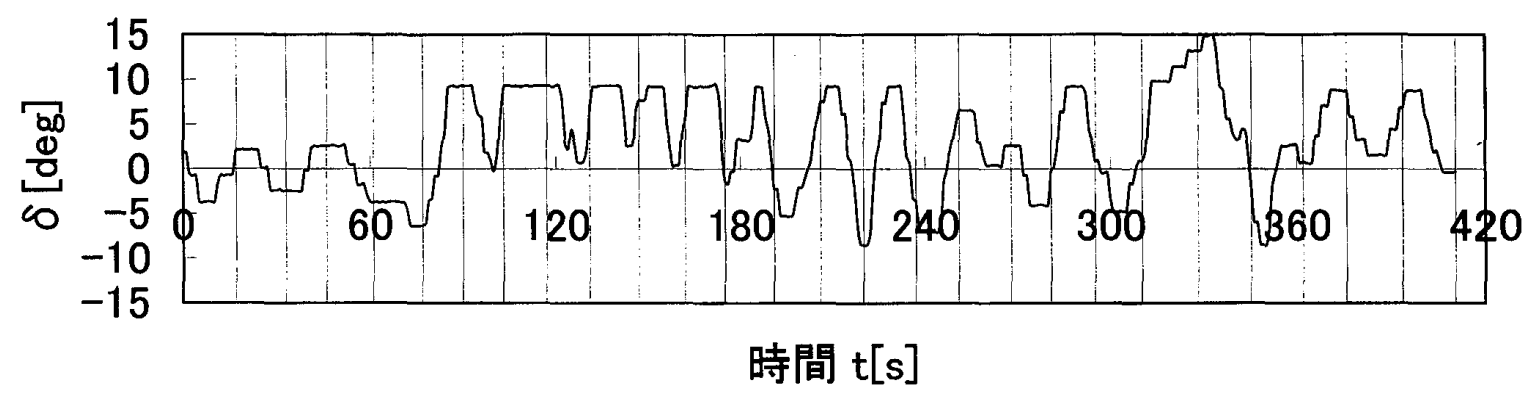

図 4 (b) 舵角変化

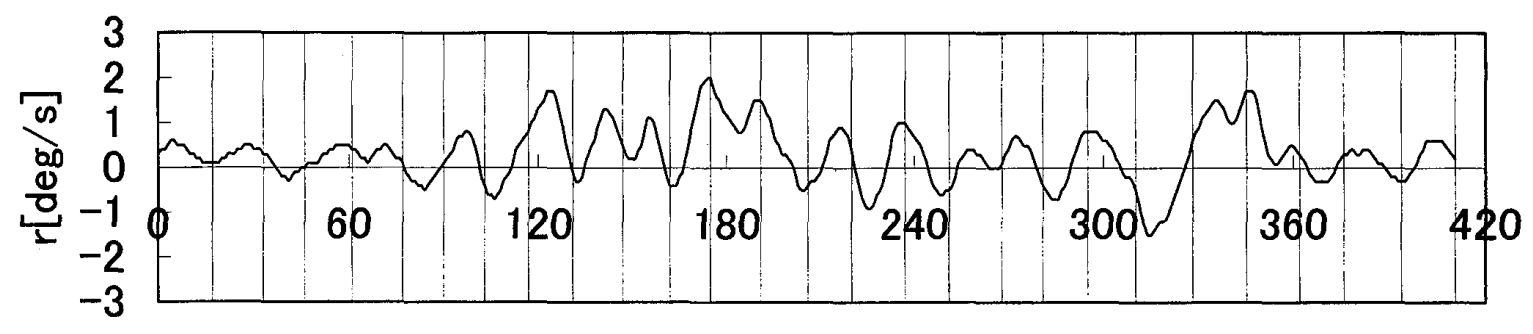

時間 $t[s]$

図 4 (c) 回頭角速度変化

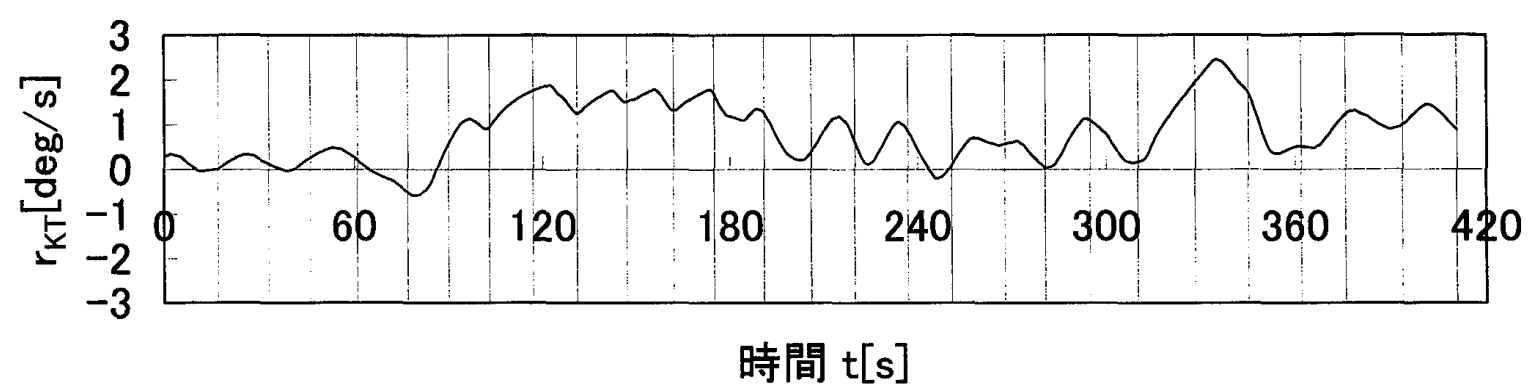

図 4 (d) 推定回頭角速度変化

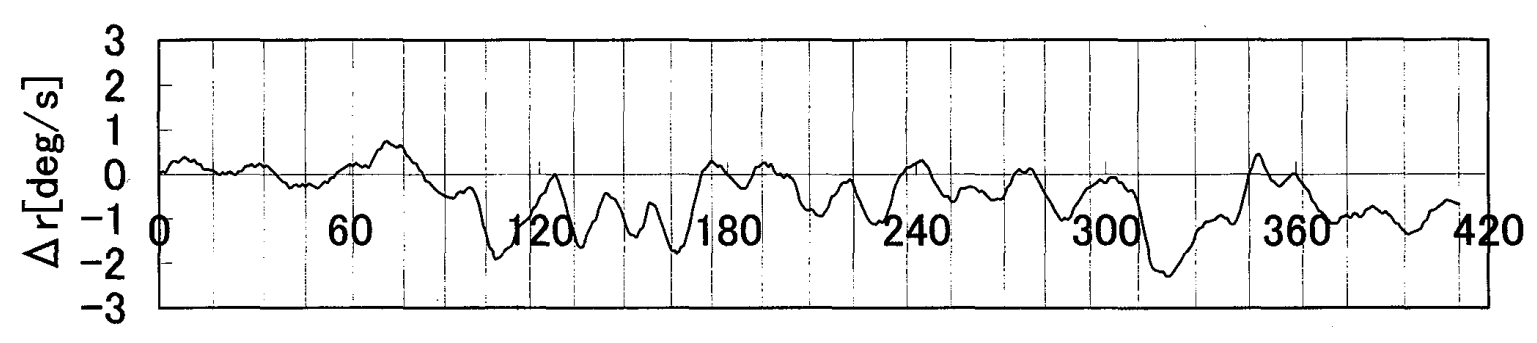

時間 $\mathrm{t}[\mathrm{s}]$

図 4 (e) 外乱変化 


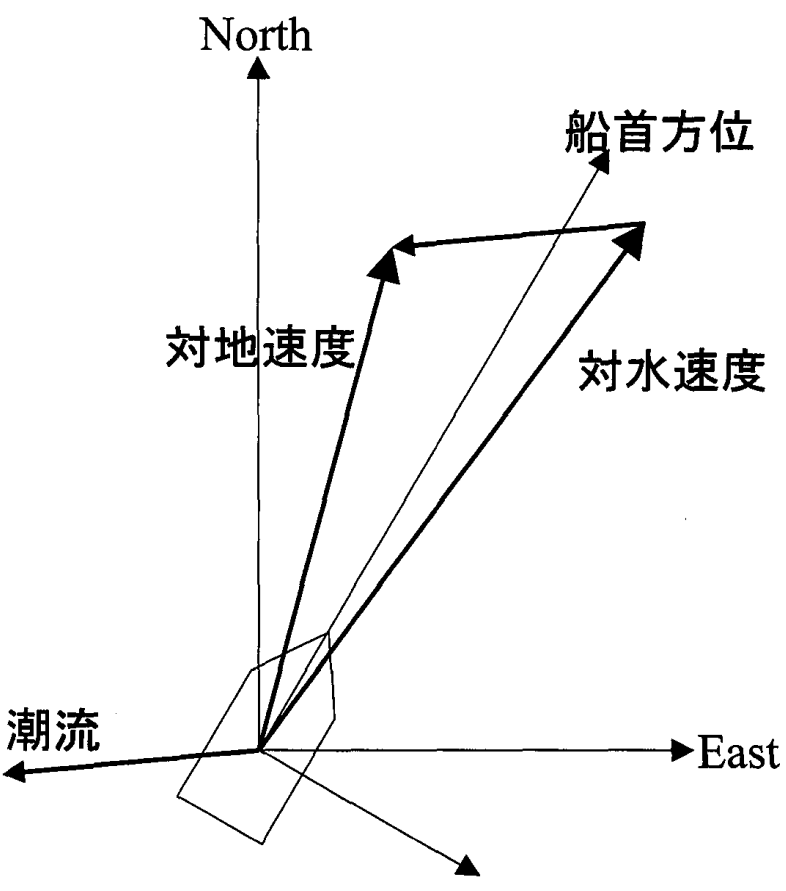

図 5 対水速度の推定方法

\section{と考えられる。}

図中の○印は、前節で大きな外乱が働いていると 述べた区間の周辺である、 $t=77[\mathrm{~s}]$ から $t=191[\mathrm{~s}]$ までの範囲（区間 6 から区間13）である。この間は 船首方位と対水速度べクトルのなす角は大きな值 (15 degから $30 \mathrm{deg})$ となっており、斜航状態が続い ていると考えられる。この状態は約 2 分程度の間起 きていることがわかる。図 7 は可視化ソフトウェア で拡大画面であり、船首方位、対地速度べクトル、

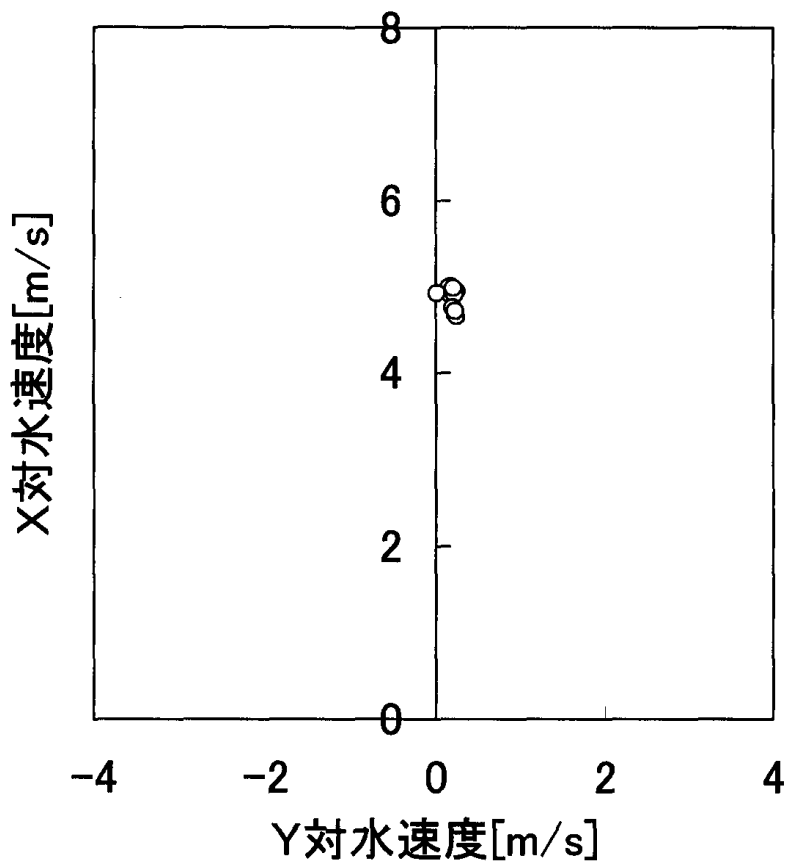

図 6（a） 対水速度（Z試験時）
潮流ベクトルを示しており、この図からも斜航状態 がわかる。このような斜航状態の場合では、平水中 での $K T$ モデルの適応範囲から外れているものと考 えられる。

その後の $t=191[\mathrm{~s}]$ から $t=310[\mathrm{~s}]$ までの範囲（区 間14から区間21）では、再び船首方位と対水速度べ クトルのなす角は小さな值に戻っている (○印)。前 節でも述べたように、強潮流下ではあるものの、潮 流の流速・流向に大きな変化がないため、斜航状態 にはならずに $K T$ モデルが適応できる範囲であると 考えられる。

さらに図 $6(\mathrm{~b})$ 中の $\Delta$ は $t=310[\mathrm{~s}]$ から $t=345[\mathrm{~s}]$ までの範囲（区間22から区間23）であり、ここでも 船首方位と対水速度べクトルのなす角は大きな值

(20 degから $30 \mathrm{deg})$ となっていることから、斜航状 態になり、KTモデルの適応範囲から外れているも のと考えられる。

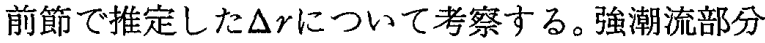
に進入する際は、まず船首を左側に振る回転モーメ ントが働く。弓削丸の全長 $40 \mathrm{~m}$ と船速から、1 船舶 長進む時間は約 10 秒であり、その間は潮流変化によ る影響と考えられる。その後の $\Delta r の$ 值は、潮流によ る影響だけではなく、斜航状態となり $K T$ モデルが 適用できない範囲であり、 $r_{K T}$ の值が実際と異なる ための影響が含まれていると考えられる。

以上、対水速度を推定し、過渡現象として斜航状 態になる場合があることを確認した。このことから、 前節で推定した外乱影響 $\Delta r$ は単なる潮流との重畳

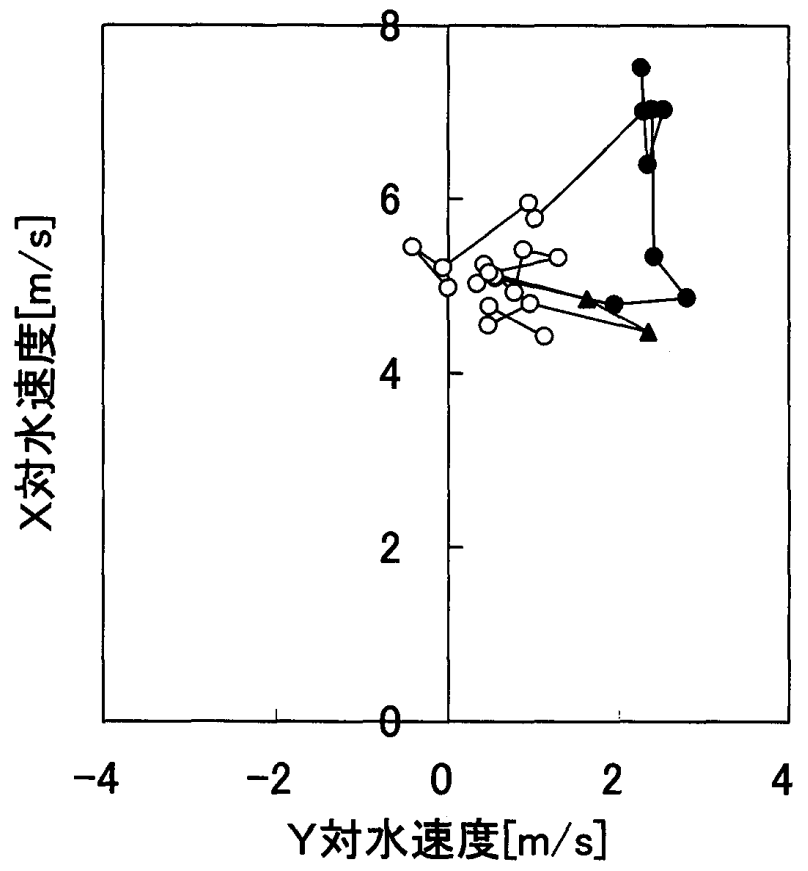

困 6 (b) 対水速度（来島海峡航行時） 


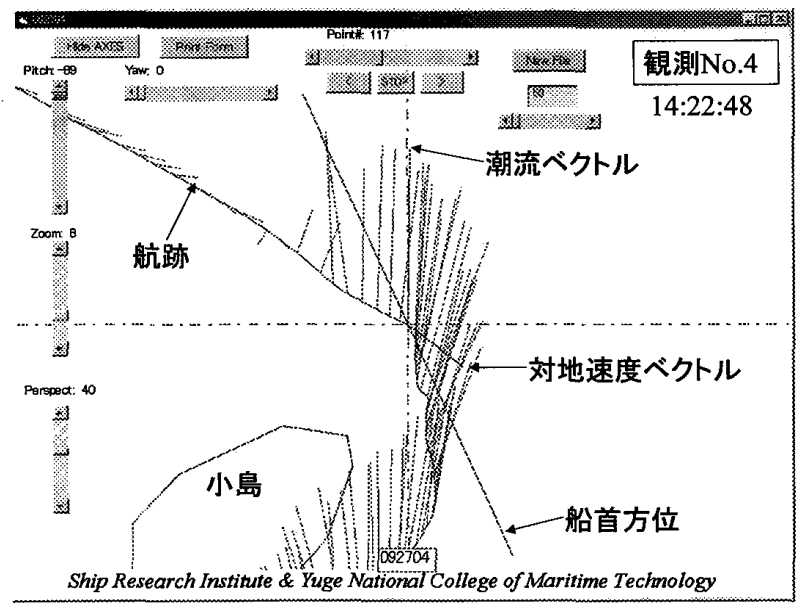

㘡 7 観測結果（拡大図）

効果だけではなく、 $K T$ モデルに従わない過渡的な 現象によるものも含まれていると考えられる。この 過渡的な現象の要因について考えてみる。Z試験の 場合、大きな変針をとっているにもかかわらず、対 水速度は船首方位で、一定の值をとっている。一方、 今回の解析区間においては、強潮流区間に突入し船 首が振られ、その後は斜航状態が続き、短時間では 対水速度が船首方位に戻らない現象が起きており、 $K T$ モデルが適応できないものと考えられる。 $K T$ モデルは平水中の運動、すなわち対水速度の方向が 船首方位であることが条件の一つであるため、今回 のように斜航状態が長時間続く場合は、舵角を切っ ても、舵角量通りの水流が舵に当たらず、舵が効か ない状態、すなわち $K T$ モデルに従わない状態に陷 るものと考えられる。

\section{6 ビデオ画像の活用}

3.4節でふれたビデオ画像で確認できた潮目突入 前後の画像を図 8 に示す。図 8 (a) は潮目突入前

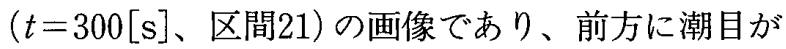

確認できる。図 $8(\mathrm{~b})$ は潮目突入後 $(t=322[\mathrm{~s}]$ 、区間 22）の画像であり、船首が左側に振られ、正面が馬 島に変わっていることがわかる。今回はビデオの再 生により潮目を確認しているが、宮㟝・桐谷らによ りリアルタイム解析を行う波浪計測システムの開 発(4) も進められており、潮目の検出が可能になり、 潮目の影響を相殺する舵角量を求めることができれ ば、有効な操船支援システムの一つになる。

\section{7 操船方法に対する考察}

図 4(b)は、舵角を示しているが、この操船方法に ついて考察を加える。区間 6 から右へ変針するため に、数回に分けて、舵角を約 $10 \operatorname{deg}$ と $0 \operatorname{deg}$ 繰り返 しとるBangーBang制御をとっている。しかしなが ら区間 8 までの船首方位は、右旋回するための舵角 をとっているにもかかわらず、ほぼ一定である。回 頭角速度をみても負の值をとることがあり、潮流の 影響や斜航状態により、船首が右に向かないことを 示している。このことから強調流部分に進入する際 には、まず船首が左に振られるモーメントが㗢くた め、まずそのモーメントを相殺する当て舵をとり、 一旦舵角を $0 \mathrm{deg}$ に戻し、右旋回への対応は次のス テップ以降で行っていることがわかる。また潮目に 突入する際には、目視によりこれを確認し、経験則 に基づく予測、突入時には船の波切り音が変化する ことなどにより、当て舵をとるタイミング决定して いる。

このように潮流変化が大きい場所や潮目に突入す る際は、まず船首が振られるのを相殺するための舵 を切り、その後旋回するための舵を切っている。当 て舵のとるタイミングは波切り音の変化などがきっ かけとなる。

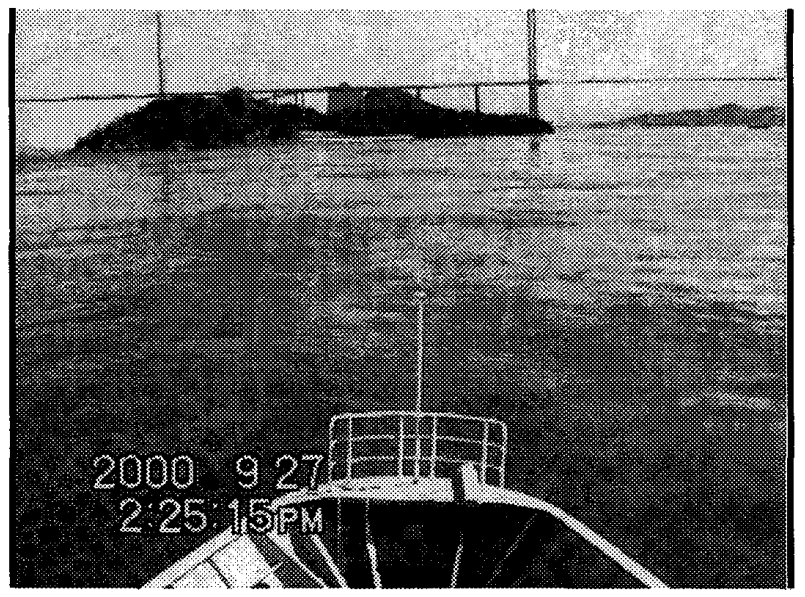

図 8 (b) ビデオ画像 $(t=322[\mathrm{~s}])$

図 8 (a) ビデオ画像 $(t=300[\mathrm{~s}])$ 


\section{4.まとめ}

来島海峡といった強潮流下において、潮流に応じ た操船方法を確立するために、弓削丸で来島海峡の 潮流と船体運動ならびにビデオにより海面の観測を した。

Z試験結果から $K T$ モデルの操縦性指数を求め、回 頭角速度についてこの指数を基にした推定值と実際 の観測結果を比較し、潮流が船体運動へ与える影響 を評価した。しかし対水速度を求めたところ、 $K T$ モ デルによる推定值が適用できない斜航状態が続くと いう過渡現象が起きる場合があることがわかった。 この現象は、潮目に突入する場合等が顕著であり、 ビデオ画像により確認することができた。

今後は斜航状態における船体運動のモデル化やビ デオ画像からの潮目の検出、当て舵量の推定方法、 波切り音の変化を検出し当て舵を取るタイミングの 決定方法などについて検討を行い、安全かつ效率的 な操船方法の確立を目指したい。

\section{謝 辞}

本研究は運輸省船舶技術研究所 (現在、独立行政 法人海上技術安全研究所）と国立弓削商船高等専門 学校との共同研究として行った。観測には弓削丸船 長をはじめ、関係各位に協力して頂いた。この場を 借りて感謝の意を表する。

\section{参 考 文 献}

（1）多田光男 - 村山雄二郎 - 沼野正義 - 緒方純俊： 来島海峡航路内での流動構造と船体挙動の観 察, 日本航海学会論文集, 第100号, pp.113-119,
1999.

（2）丹羽康之 - 沼野正義 - 福戸淳司 - 室原陽二：強 潮流下に打ける弓削丸の操縦軍動解析, 日本航 海学会論文集，第101号，pp.103-108，1999.

(3) Mitsuo Tada et al. : "Development of 3D Tool for Tidal Current and Ship Movement Analysis and Its Application to Real Observations", Proceedings of ECM\&SP '99, 1999.

（4）宮㟝 剛・桐谷伸夫他：ビデオ画像を用いた船 側相对水位計測手法の開発，平成13年度海上技 術安全研究所研究発表会講演集, pp.55-58, 2001.

\section{質 疑 応 答}

大津皓平 (東京商船大学)：強潮流下のモデルとし て、それではどのように $K T$ モデルを変更すれば 良いのか、見通しはありますか。

丹羽康之：今回の解析結果で明らかにしたことは、 潮流の変化等により船首が振られ、その後斜航状 態が続くことがあり、KTモデルの適応範囲外の 運動になるということであります。今後の検討課 題として、KTの数值自身に潮流影響のパラメー 夕を加えるモデルを作成することが考えられます が、その前に画像等からにより、定量的な舵角操 作量の算出を行う必要があると考えられます。そ れが実現できれば、 $K T$ モデルの変更が可能にな るものと考えております。また、海面状態の観測 により、斜航状態に陥らないようなコース取りの ための情報を得ることが有効な支援となると考え ます。 